\title{
Analysis and selection of parental forms for crossbreeding of early potatoes for the arid conditions of the Middle Volga region
}

\author{
Vladimir Molianov ${ }^{1}$, Oleg Vinogradov ${ }^{2 *}$, and Natalya Ivanayskaya ${ }^{3}$ \\ ${ }^{1}$ Molianov Agro Group LLC, 446442 Kinel, Samara Region, Russia \\ ${ }^{2}$ Union of Potato Growers of the Samara Region NPP, 443111 Samara, Russia \\ ${ }^{3}$ Agrostar LLC, 446494 Pokhvistnevsky District, Samara Region, Russia
}

\begin{abstract}
In the modern changing climate, selective breeding has been essential for increasing production and ensuring stable yields. Potato varieties with different ripening periods are suitable for the conditions of the Middle Volga region. High-yielding varieties resistant to mechanical damage and diseases, varieties with increased heat resistance and a complex of other important features are being created. The emergence of new directions has complicated the solution of breeding programs and required the organization of an intermediate stage in this work: the identification and use of special parent forms - carriers of useful qualities. This is a basic, but necessary task when involving a variety of genetic material in the selection process. Research on the topic was carried out in 2017-2019 in the Samara region (RF) in a special shielded area of AGROSTAR LLC in cooperation with experts of the potato farm of VNIIKH FGBNU, MAG LLC (Kinel), Agrocenter Korenevo LLC, and with the participation of experts of Bavaria-Saat GmbH, Germany.
\end{abstract}

\section{Introduction}

Maintaining the conditions necessary to keep modern potato varieties in the optimum selling condition during long periods of storage is expensive. This expense significantly increases the overall cost of the product. For this reason, potato farmers in central Russia are in extreme need of potato varieties with new advantageous characteristics and a faster ripening period.

To carry out a thorough selection for the optimum breeds of super early potato varieties, they must be matched with predetermined economically valuable traits. The right selection of parental pairs is made according to the following main indicators: the number of tubers per bush, average weight, as well as the main characteristics of the tubers. Since the inheritance of beneficial characteristics of potatoes is due to aspects of gene interaction, the analysis and selection of parental forms allows one to achieve certain indicators in the process of breeding [1].

To date, a new source material of varieties and strains of potatoes of different origin has been collected in our breeding center. Most of this material requires the study of its offspring. This will make it possible soon to use parental forms in breeding programs. It is also necessary to clarify the criteria for selecting parental pairs according to the shape of the tuber, the depth of the eyes, and the various characteristics of the crop in order to meet modern demand requirements.

\section{Material and methods}

The main goal of the work was to determine effective parental forms and their combinations that would produce offspring that achieves a high percentage of given economically valuable traits and their ability to be used in further breeding programs. As a result of the selection, parental forms were used for inter-variety hybridization, which is widely performed for breeding potato varieties both in Russia and abroad (France, Germany and Holland). When using this method, it is important to choose the right crossbreeding components to obtain a large volume of hybrid populations for distinguishing hybrids with economically valuable traits $[2,3]$.

Scientific originality. The super early varieties, for the Middle Volga region, displaying the most important characteristics were investigated.

The most effective parent forms were selected, and out of these, their combinations were selected for use in the breeding process.

Agricultural production requirements for creating potato varieties are constantly growing and in the near future will include not only high and stable productivity, resistance to biotic and abiotic environmental factors, the most harmful diseases and pests, but also adaptation to soil and climatic conditions for cultivation, as well as excellent product characteristics and nutritional value.

For earlier varieties, storage time was not as desirable a characteristic as heat resistance, suitability for harvesting at temperatures above $+21^{\circ} \mathrm{C}$ (as a limiting

Corresponding author: molianov@yandex.ru 
factor when harvesting early potatoes), absence of darkening and damage to the skin during harvesting.

The degree of influence of the shelf life of seeds on germination and further development was determined by sowing seedlings grown from seeds of domestic hybrids, as well as crossed with seeds of German and French varieties. In this case, the potato seeds were soaked for a day in distilled water, dried and sown on April 22 in pallets filled with previously prepared soil.

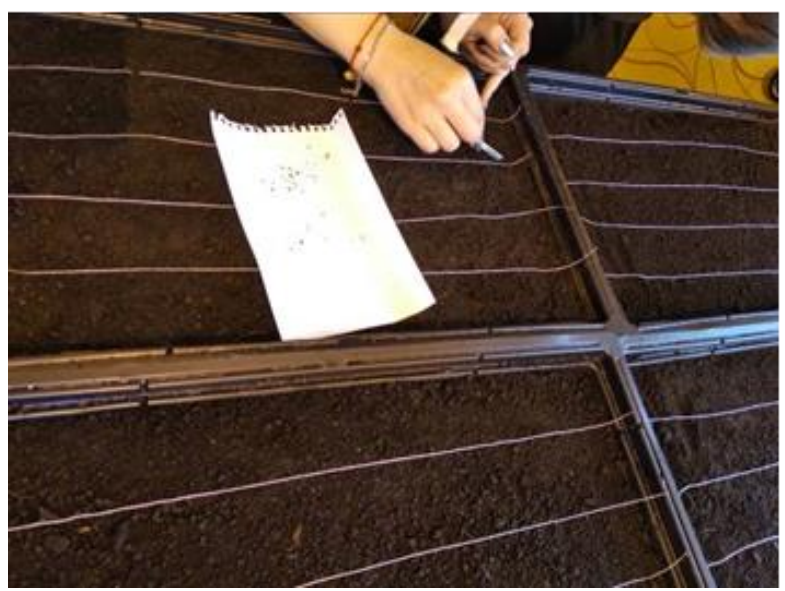

Fig. 1. Sowing of seed material

The soil was prepared as follows: thoroughly mixed four parts of separated peat with two parts of soddy soil and one part of river sand, then moistened the soil with water, covered with a film (provoked weed seeds to germinate), removed weeds, moistened the soil with water and treated with "Bisolbisan" preparation based on Bacillus subtilis strains. Potato seeds were soaked for 24 hours with "Fitosporin", a preparation based on the bacteria Bacillus subtilis, then dried.

Sowing was carried out according to the scheme: row-spacing of $5 \mathrm{~cm}$, between seeds distance of $2.5 \mathrm{~cm}$. Seeds were covered with a layer of sand $0.5 \mathrm{~cm}$. Compacted and covered then with a film until germination. Ventilated daily until germination.

The pallets were placed in a specially equipped room and kept at a temperature of $20-22{ }^{\circ} \mathrm{C}$ until full emergence. After the appearance of mass seedlings (May 2-4), the following temperature conditions were kept during the day $15-18^{\circ} \mathrm{C}$, at night $7-9^{\circ} \mathrm{C}$.

For 4-5 days, the hybrids were tempered: cups with seedlings were taken out at a temperature of $6-8{ }^{\circ} \mathrm{C}$ and left in partial shade for $2-3$ hours, with a daily extension of the exposure time by 1.5-2 hours.

The seedlings were planted on May 18 in specially prepared 9x9 $\mathrm{cm}$ cups, previously locally applying mineral fertilizers to them at the rate of N60P90K90 kg a.i. per ha. By this time, the seedlings reached a height of 2-3 cm and managed to form 4-5 real leaves. During the planting period, the day lasted 18-19 hours, the average daily temperature was $8.4-8.7^{\circ} \mathrm{C}$, and the soil $10.0_{-}$ $11.5^{\circ} \mathrm{C}$.

During the growing season, watering, weeding, top dressing and treatment with fungicides (Concento, Luna, Tranquility, Infinito), as well as insecticides (Cirocco, Aktara) were regularly carried out.

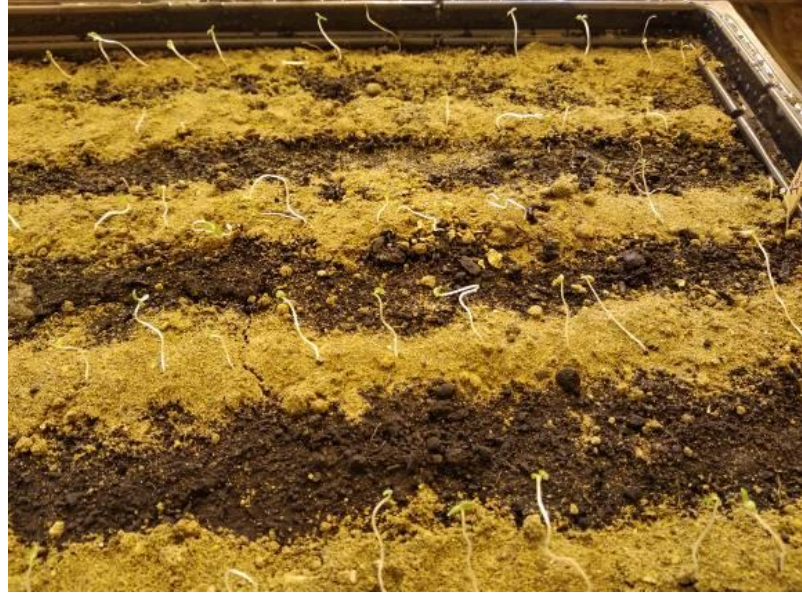

Fig. 2. Emergence of seedlings.

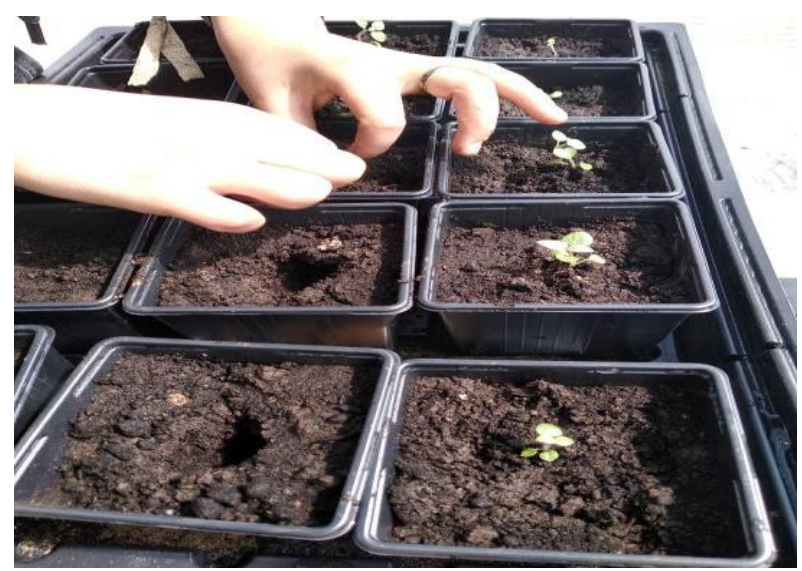

Fig. 3. Picking seedlings into pots.

\section{Results}

Existing domestic potato varieties do not fully meet the predetermined economically valuable trait requirements. These varieties displayed an instability of yield and decrease in production due to influence of adverse external conditions, as well as a result of diseases and pests.

As a result of this, several tasks to be performed prior to the selection process have been identified, which can split into 3 parts namely: general, zonal and special.

General task was to create varieties that are ecologically malleable, high-yielding, resistant to diseases, pests and unfavorable conditions with different ripening periods, high nutritional value and good taste and suitable for mechanized cultivation $[4,5]$.

The most important of the zonal tasks is the breeding of heat-resistant super early ripening varieties for irrigated arable farming under the conditions of high soil and air temperature $[6,7]$.

We did not set special objectives for the selection and analysis of varieties suitable for processing purposes. In future years, when selecting the achieved generations with the participation of the parental form (Innovator, Velox), it is planned to conduct a study on the suitability for processing into french fries. 
Breeding includes three fundamental methods: selection of parental pairs, hybridization and selection of the most valuable forms.

In potato breeding, hybridization is the main method of creating new populations/forms for selection. The pedigree of modern potato varieties shows that they are obtained by selection from hybrid populations, individual valuable traits, or their combinations, which are absent from the cultural species $S$. tuberosum (immunity to viruses, late blight, nematode) $[8,9]$.

The success of hybridization fundamentally depends on the proper selection of parental pairs. A.S. Serebrovsky confirms this by saying, "Selection of pairs is the pinnacle of breeding, the most creative part of it" [10].

If the corresponding parents, whose genes are to be recombined into a new variety, are not properly selected, significant success cannot be achieved, despite the creation of a model and desired type of variety. Only the correct selection of forms determines the success of the selection conducted by the breeder $-\mathrm{S}$. Borevich notes [11].

\subsection{Selection for resistance to viruses}

Creating varieties with resistance to viral diseases is one of the most difficult tasks of breeding. The difficulty lies in that there is a large variety of viruses with varying strains whose nature of the manifestation varies depending on external conditions and potato varietal specificity.

The deciding factor here is the choice of source material based on the knowledge of the genetic nature of varieties with various types of resistance and the patterns of their inheritance [12]. For our research, varieties with high resistance to the $\mathrm{Y}$ virus, such as Arose, Gala, Granada, Queen Anne, Vitesse were considered in 2018. In addition to these, the Bettina variety, also immune to the Y virus, is planned to be considered in 2019.

\subsection{Selection for resistance to cancer}

Potato cancer is caused by the fungus Synchytrium endobioticum and is a dangerous disease that should be quarantined. On the territory of our country, Russia, four biotypes of cancer have been identified. All varieties entering government variety testing should be resistant to the normal strain of fungus. Many breeding varieties, wild and cultivated potato varieties are immune to it [13, 14]. The selection of the main parental forms was based on their proven resistance to one of the cancers' strains.

\subsection{Breeding for resistance to potato nematode}

Potatoes damage two types of helminth - Globodera rostochiensis (golden) and Globodera pallida (white). The yellow nematode is represented by the Rol-Ro5 patotypes, the white - Pal-Pa3 [15]. Nematode is common in all countries with developed potato farming. Monogenic resistance to nematodes is controlled by independent dominant $\mathrm{H} 1$ genes in $S$. andigenum, Gro IV in S. vernei and Gro 1 in S. spegazzinii, S. kurtzianum [16]. From the collection of nematode-resistant varieties, we have identified valuable source material for this direction of selection, combining resistance to nematode with other economically valuable traits. We have planned for the analysis of populations of various parental pairs with resistance to golden nematode, as well as the variety Laperla, which has resistance to the white nematode, Globodera pallida.

However, hybrids receive from parents not only "planned" genes by the breeder, as a basis for development of specific useful traits, but also other hereditary genes, which include stimulation of negative traits [17].

As a result of a comprehensive assessment of the modern assortment, samples with a high level of indicators were selected, which were used as sources for breeding for early maturity, productivity, quality indicators, resistance to late blight and nematode (Table 1).

Table 1. Analysis of parental forms by genetic sources (parental forms) of the main economically useful traits of potatoes, 2017-2019

\begin{tabular}{|c|c|}
\hline Traits & Parental Forms (Varieties) \\
\hline Maturity (earliness) & $\begin{array}{l}\text { Gulliver, Capri, Riviera, } \\
\text { Juvel, Colombo, Colette, } \\
\text { Meteor, Bellerose, Rosara, } \\
\text { Velox, Impala, Laperla }\end{array}$ \\
\hline $\begin{array}{l}\text { High productivity (yield, } \\
\text { marketability) }\end{array}$ & $\begin{array}{l}\text { Juvel, Colette, Arose, Red } \\
\text { Lady, Vinetta, Secura, } \\
\text { Rainbow }\end{array}$ \\
\hline White flesh & 7for7, Aurora \\
\hline Red skin & $\begin{array}{c}\text { Arose, Romanze, Red } \\
\text { Scarlett, Red Lady, } \\
\text { Typhoon, Desiree, Red } \\
\text { Fantasy, Rosara, Evolution, } \\
\text { Roco, Eldorado, Aurora, } \\
\text { Labella }\end{array}$ \\
\hline $\begin{array}{c}\text { Peel strength with early } \\
\text { harvesting }\end{array}$ & Velox, Nandina \\
\hline Virus resistance to virus $\mathrm{Y}$ & $\begin{array}{c}\text { Bettina, Granada, Arose, } \\
\text { Gala, Queen Anne, Aurora, } \\
\text { Vitesse } \\
\end{array}$ \\
\hline $\begin{array}{l}\text { High resistance to late blight } \\
\text { Pathogen: Phytophthora } \\
\text { infestans (Mont.) de Bary }\end{array}$ & $\begin{array}{c}\text { Nandina, Red Lady, Secura, } \\
\text { Romanze }\end{array}$ \\
\hline $\begin{array}{c}\text { Resistance to the golden } \\
\text { potato nematode }\end{array}$ & All varieties \\
\hline $\begin{array}{l}\text { Combinations of } \\
\text { economically useful traits } \\
\text { (form of tubers, depth of } \\
\text { eyes, number of tubers, } \\
\text { safety of tubers) }\end{array}$ & $\begin{array}{c}\text { Madeira, Secura, Gala, } \\
\text { Natasha, Queen Anne, } \\
\text { Vitesse, Rainbow, Evolution }\end{array}$ \\
\hline
\end{tabular}

The obtained hybrid combinations in 2018 were sown in the VNIIKH FGBNU on the site of the Agricultural Center Korenevo LLC. The seedlings were planted for further selection based on the results of 2019. The best conjunction of combinations obtained by crossing from 60 pieces where - Ramos x Velox, Gulliver x Gala, Aluet x Innovator.

Plans for further research in 2019 included complex tests and analysis of the resulting combinations. There are plans to conduct the study of the germination of hybrid combinations (seedlings) with different parental 
forms when crossed from previous years. The study involved the seeds obtained since 2012 (table 2).

As the experience of sowing seeds from different periods of crossing showed, the dependence on the number of years of storage was minimal. On average $71.5 \%$ seed germination was found. The differences in germination fit into an average statistical error of less than $5 \%$. The best germination rate was $91.1 \%$ for the strain 171517 (2015). The worst germination rate was $42.6 \%$ for the strain 091309 (2013).

Table 2. Germination of potato seeds obtained from VNIIKH GBNU (Sowing in the greenhouse number 1 Agrostar LLC in 2019)

\begin{tabular}{|c|c|c|c|c|c|}
\hline Strain & $\begin{array}{l}\text { Maternal } \\
\text { parental } \\
\text { form }\end{array}$ & $\begin{array}{l}\text { Paternal } \\
\text { parental } \\
\text { form }\end{array}$ & $\begin{array}{l}\text { Sown } \\
\text { seeds, } \\
\text { pcs. }\end{array}$ & $\begin{array}{c}\text { Ascen } \\
\text { ded, } \\
\text { pcs. }\end{array}$ & $\begin{array}{c}\text { Germina } \\
\text { tion, } \%\end{array}$ \\
\hline \multicolumn{6}{|c|}{2012} \\
\hline 1201 & Roco & $88.16 / 20$ & 56 & 41 & 73.2 \\
\hline 1202 & Red Scarlett & $128-6$ & 56 & 45 & 80.4 \\
\hline 1203 & Impala & $128-6$ & 57 & 54 & 94.7 \\
\hline 1204 & Romanze & $128-6$ & 54 & 47 & 87.0 \\
\hline 1205 & Sante & Bryansky N & 59 & 31 & 52.5 \\
\hline 1206 & Roco & Valentine & 45 & 41 & 91.1 \\
\hline 1207 & $\mathrm{~B} / \mathrm{y} 97.19-2$ & Velox & 56 & 47 & 83.9 \\
\hline 1208 & Agatha & $88.34 / 14$ & 57 & 40 & 70.2 \\
\hline \multicolumn{3}{|c|}{ Total per year } & 55.0 & 39.3 & 71.4 \\
\hline \multicolumn{6}{|c|}{2013} \\
\hline 1309 & Colette & Gala & 54 & 23 & 42.6 \\
\hline 1310 & Red Fantasy & $2292-20$ & 57 & 43 & 75.4 \\
\hline 1311 & Romano & $190-4$ & 54 & 52 & 96.3 \\
\hline \multicolumn{3}{|c|}{ Total per year } & 55.0 & 39.3 & 71.4 \\
\hline \multicolumn{6}{|c|}{2014} \\
\hline 1412 & Impala & Aurora & 57 & 32 & 56.1 \\
\hline 1413 & Roco & Aurora & 56 & 30 & 53.6 \\
\hline 1414 & Impala & Sarpo Mira & 52 & 36 & 69.2 \\
\hline \multicolumn{3}{|c|}{ Total per year } & 55.0 & 32.7 & 59.6 \\
\hline \multicolumn{6}{|c|}{2015} \\
\hline 1415 & Arose & $88.16 / 20$ & 57 & 35 & 61.4 \\
\hline 1516 & Colette & Breeze & 52 & 34 & 65.4 \\
\hline 1517 & Roco & Breeze & 56 & 51 & 91.1 \\
\hline 1518 & Vitesse & $92.7-26$ & 51 & 30 & 58.8 \\
\hline 1519 & Utenok & Tiras & 56 & 45 & 80.4 \\
\hline 1520 & Vitesse & Aurora & 52 & 29 & 55.8 \\
\hline \multicolumn{3}{|c|}{ Total per year } & 54.0 & 37.3 & 68.8 \\
\hline \multicolumn{6}{|c|}{2017} \\
\hline 1721 & Vinetta & Gala & 54 & 39 & 72.2 \\
\hline 1722 & Colette & Gala & 54 & 28 & 51.9 \\
\hline 1723 & Red Scarlett & Gala & 30 & 22 & 73.3 \\
\hline 1724 & \begin{tabular}{|l|} 
Kristel \\
\end{tabular} & Bellerose & 30 & 25 & 83.3 \\
\hline 1725 & Colette & Bellerose & 58 & 47 & 81.0 \\
\hline 1726 & Vinetta & Bellerose & 30 & 25 & 83.3 \\
\hline 1727 & Gulliver & Bellerose & 55 & 51 & 92.7 \\
\hline 1728 & Granada & Bellerose & 57 & 48 & 84.2 \\
\hline 1729 & Vinetta & Vinetta & 30 & 21 & 70.0 \\
\hline \multicolumn{3}{|c|}{ Total per year } & 38.2 & 29.7 & 68.9 \\
\hline \multicolumn{6}{|c|}{2018} \\
\hline 1830 & Impala & Breeze & 56 & 49 & 87.5 \\
\hline 1831 & Desire & Breeze & 65 & 38 & 58.5 \\
\hline 1832 & Eldorado & Breeze & 65 & 36 & 55.4 \\
\hline 1833 & Ferrari & Breeze & 60 & 37 & 61.7 \\
\hline 1834 & Red Scarlett & Bellerose & 61 & 44 & 72.1 \\
\hline 1835 & Eldorado & Bellerose & 57 & 27 & 47.4 \\
\hline 1836 & Crone & $88.34 / 14$ & 58 & 46 & 79.3 \\
\hline \multicolumn{3}{|c|}{ Total per year } & 60.3 & 39.6 & 66.0 \\
\hline \multicolumn{3}{|c|}{ Total amount 2012-2018 } & 1914 & 1369 & 71.5 \\
\hline
\end{tabular}

\section{Conclusion}

1. The varieties with a complex of biological and economically valuable traits that are effectively used in breeding for early ripening and high productivity have been isolated from the modern potato gene pool.

2. Genetic sources of resistance to the white potato nematode is the Laperla variety, which is involved in the further selection process for complex resistance to pathogens.

3. Criteria for selecting varieties and interspecific hybrids for crossing significantly influence the processes in hybrid populations and predetermine the effectiveness of creating hybrids with planned qualities.

4. Experimentally confirmed the absence of the influence of the time of crossing and storing seeds for germination (2012-2018).

\section{Suggestions}

For use in the breeding process, we recommend the following genetic sources for the traits:

Early Maturity - Capri, Impala, Riviera, Velox.

Productivity - Secura, Rainbow, Lilly.

Red skin - Red Lady, Typhoon.

The main result of the practical crossbreeding was the creation of two strains №XXXX-X7, №XXXX-X8 potatoes, which were submitted for tests on nematode resistance and cancer resistance, and application for state tests and registration of the State Register Russian Federation in 2020-2021 as the result of a positive test.

\section{References}

1. Evaluation of Potato Cultivars for Resistance against Water Deficit Stress under in Vivo Conditions Potato Res. 53, 383-392 (2010) DOI: 10.1007/s11540-010-9179-5.

2. J. Buijs, M. Martinet, F. de Mendiburu, M. Ghislain, Potential adoption and management of insectresistant potato in Peru, and implications for genetically engineered potato Environ. Biosafety Res. 4, 179-188 (2005) DOI: 10.1051/ebr:2006002.

3. J. Heldak, E. Brutovska, A. Gallikova, Selection of valuable potato genotypes with introduced resistance genes derived from wild species Agricult. 55(3), 133-139 (2009)

4. L.B. Sergeeva, The influence of growing conditions on the yield and quality of potatoes in the Middle Urals, dissertation (Yekaterinburg, 2015)

5. A. Khan, V. Sovero, D. Gemenet, Genome-assisted Breeding for Drought Resistance Current Genomics 17(4), 330-342 (2016) DOI: $10.2174 / 1389202917999160211101417$.

6. T. Dronova, I. Dergacheva, Irrigated Agricult. 1, 6-7 (2013)

7. Y. Wang, K.J. Yang, X.C. Gong, L.P. Qi, Y. Feng, C. Liu, J. Yin, Evaluation of drought resistance in 
major potato cultivars Seed 35(9), 82-85 (2016) DOI: 10.16590/j.cnki.1001-4705.2016.09.082.

8. O. Prokhorova, Evaluation of hybrid potato populations from different types of accumulating crosses by field (horizontal) resistance to late blight and the creation of source material for selection, PhD dissertation (Moscow, 2013)

9. Y. Li, C. Colleoni, J. Zhang, Q. Liang, Y. Hu, H. Ruess, R. Simon, Y. Liu, Genomic Analyses Yield Markers for Identifying Agronomically Important Genes in Potato Mol. Plant 11(3), 473-484 (2018) DOI: 10.1016/j.molp.2018.01.009.

10. A.S. Serebrovsky, Genetic analysis (Nauka, Moscow, 1970)

11. S. Borevich, Principles and methods of plant breeding (Kolos, Moscow, 1984)

12. R. Sharmaa, Vinay Bhardwaja, Dalamu Dalamua, S.K. Kaushikb et al., Identification of elite potato genotypes possessing multiple disease resistance genes through molecular approaches Scientia Horticulturae 179, 204-211 (2014)
13. D.V. Abrosimov, The principles of selection of parental pairs and selection methods for the breeding of potatoes for increased starchiness, $P h D$ dissertation (Moscow, 2007)

14. A.V. Khutti, O.Yu. Antonova, N.V. Mironenko, T.A. Gavrilenko, O.S. Afanasenko, Potato resistance to quarantine diseases Vavilov $\mathrm{J}$. of Genet. and Breeding 21(1), 51-61 (2017) DOI: 10.18699 / VJ17.223 (In Russ.)

15. S.B. Abrosimova, Improvement of methods for breeding potatoes for resistance to a golden cystforming nematode (globodera rostochiensis (woll.), PhD dissertation (Moscow, 2014)

16. I.M. Yashina, L.I. Kirsanova, G.I. Uzhovskaya, To the methodology for the selection of parental pairs for potato hybridization Sci. tr. Research Institute of Potato 33, 22-30 (Moscow, 1979)

17. M. Tester, P. Langridge, Breeding technologies to increase crop production in a changing world Sci. 327, 818-822 (2010) DOI: 10.1126/science. 1183700 